\title{
PHYSICO-MECHANICAL AND RELEASE PROPERTIES OF SUSTAINED RELEASE ARTESUNATE TABLETS IN HYDROXYPROPYL METHYLCELLULOSE MATRIX
}

\author{
MUSILIU ADEDOKUN ${ }^{1 *}$, BENJAMIN ONAH ${ }^{2}$, ANTHONY ATTAMA ${ }^{2}$
}

${ }^{1}$ Department of Pharmaceutics and Pharmaceutical Technology, Faculty of Pharmacy, University of Uyo, Uyo, Nigeria, ${ }^{2}$ Department of Pharmaceutics, Faculty of Pharmaceutical Sciences, University of Nigeria, Nsukka, Nigeria

Email: mo_adedokun@yahoo.com

Received: 01 Sep 2017, Revised and Accepted: 28 Nov 2017

\section{ABSTRACT}

Objective: This work was aimed at formulating artesunate tablets with hydroxypropyl methylcellulose (HPMC)-a hydrophilic polymer for the purpose of achieving a sustained release profile of the drug and evaluating their properties.

Methods: The solubility profile of artesunate was determined in water, methanol, ethanol, ethanol/water mixtures (50/50, 40/60 v/v), simulated intestinal fluid (SIF) without enzymes (pH 7, 7.2 and 8), simulated gastric fluid (SGF) without enzymes (pH 1.2), 0.1N hydrochloric acid (HCI), 0.1N sodium hydroxide $(\mathrm{NaOH}), 0.1 \mathrm{~N}$ acetic acid and phosphate buffer solution, PBS (pH 7, 7.2 and 8). Four batches of oral sustained release artesunate tablets intended for once-daily dosing were formulated with $10 \%, 20 \%, 25 \%$ and $30 \% \mathrm{w} / \mathrm{w}$ concentrations of HPMC using wet granulation method. Evaluation of granule properties was done by determining the angle of repose, flow rate, bulk density, tapped density, Carr's index and Hausner's quotient. The compressed tablets were also evaluated using official and non-official parameters. Absolute drug contents were determined in $0.1 \mathrm{~N}$ $\mathrm{NaOH}$, ethanol and methanol. In vitro release was studied in different media and release kinetics mechanism elucidated. In vivo studies were carried out using healthy Wistar rats.

Results: Artesunate was observed to exhibit solubility at varying degrees depending on solvents or media employed as well as the pH of the media. All the granule batches have Hausner's quotient value of approximately 1.2. The values for Carr's index for all the batches ranged between 30 and 40 . The angle of repose, Carr's index and Hausner's quotient values indicate good flow properties of the granules for all the batches. All the tablet batches conformed to official standard in terms of weight uniformity as no single tablet deviated beyond $5 \%$ from the average weight in each batch with no significant difference in the values ( $p>0.05)$. Values of hardness increased insignificantly from batches $A$ to $D(p>0.05)$. Friability values were very low and follows no specific pattern among the batches but the difference in the values was significant $(\mathrm{p}<0.05)$. Absolute drug content reduced while in vitro release times increased as hardness increased, indicating the probable progressive reduction in the tendency of the matrix to release the drug as the concentration of HPMC increased from batches A to D. $n$ values obtained from analysis of release mechanism were above 0.89 for each batch.

Conclusion: The release mechanism was shown to be complex and the release involved zero order, first order, and Higuchi model kinetics. The biological half-life of artesunate was shown to be $1.05 \mathrm{hr}$, and metabolites which bear resemblance to artesunate in absorbance seem to be encountered. In this work, HPMC matrix yielded high-quality tablets indicating its usefulness in sustained released product development.

Keywords: Sustained release, Artesunate tablet, Hydrophilic polymer, Hydroxypropyl methylcellulose, Release kinetics, Spectrophotometric assay

(c) 2018 The Authors. Published by Innovare Academic Sciences Pvt Ltd. This is an open access article under the CC BY license (http://creativecommons.org/licenses/by/4.0/) DOI: http://dx.doi.org/10.22159/ijap.2018v10i1.22918

\section{INTRODUCTION}

Post-1990 is the modern era of controlled release technology-the period in which an attempt at drug delivery optimization is emphasized [1]. Over the years, pharmaceutical dosage delivery researchers and developers have focused on approaches to arrive at more convenient, more effective and more reliable dosage delivery systems that enhance drug performance over and above the conventional ones [2]. The concept of sustained release formulation was developed to eliminate the need for multiple dosage regimens, particularly for those drugs requiring reasonably constant blood levels over a long period of time. In addition, it also has been adopted for those drugs that needed to be administered in high doses but where too rapid a release is likely to cause undesirable side effects [3]. For some drugs, the incidence of side effects as well as toxicity is believed to be a function of plasma concentration [1].

HPMC is a cellulose derivative chemically known as cellulose hydroxypropyl methyl ether. It is soluble in different solvents and their mixtures [4] and is widely used in oral and topical pharmaceutical formulations. In oral products, it is primarily used as tablet binder [5]. Depending upon the viscosity grade, concentrations between $2-20 \% \mathrm{w} / \mathrm{w}$ are used as film coating solutions in film-coated tablets. Lower viscosity grades are employed in aqueous film coating solutions while higher viscosity grades are used with organic solvents. Thus, in oral products, HPMC is used in film coating of tablets [6]. Cellulose ethers are often preferred polymers in film coating, particularly HPMC, although these polymers have been reported to retard drug dissolution $[3,4]$.
HPMC is usually employed as tablet binder at concentrations between $2-5 \% \mathrm{w} / \mathrm{w}$ in either wet or dry granulation process. High viscosity grades may be used to retard the release of drugs from a matrix at levels $10-80 \% \mathrm{w} / \mathrm{w}$ in tablets and capsules. It is also used as a binder in capsule manufacture, adhesive in plastic bandages, a wetting agent for contact lenses, pharmaceutical emulsifier, a suspending agent in topical gels and ointment, and as adjuvants in cosmetics and food products.

Artestunate is a white crystalline powder with a melting point between $132-135^{\circ} \mathrm{C}$ and is slightly soluble in water [7]. The drug is a hemi succinate derivative of dihydroartemisinin employed as an anti-plasmodial agent. Artemisinin is a sequiterpene lactone isolated form Artemisia anua, a herb that has traditionally been used in China for the treatment of malaria [8]. It has a biological half-life of less than two hours. Artesunate was thus in this research work formulated as sustained release tablet to remedy the difficulties associated with frequent dosing and to prevent the development of drug resistance.

This work was aimed at digging deeper into artesunate to generate information that would help stakeholder professionals-health care providers, researchers as well as manufacturers. It is also designed to establish and develop a simple convenient and reliable spectrophotometric method of assay for artesunate, and to study the release pattern in different concentrations of a polymer matrix and determine the suitability of the artesunate tablet formulation as oral sustained release delivery system of the drug. 


\section{MATERIALS AND METHODS}

\section{Materials}

Materials used were artesunate powder (Emzor Pharmaceutical Limited, Nigeria), HPMC (Shi-Etsu, France), lactose (May and Baker, England), stearic acid (May and Baker, England), absolute ethanol (Sigma-Aldrich, Germany), hydrochloric acid (May and Baker, England), acetic acid (BDH, England), monobasic potassium phosphate (Sigma-Aldrich, Germany), sodium dihydrogen phosphate monohydrate (Sigma-Aldrich, Germany), anhydrous disodium hydrogen phosphate (Sigma-Aldrich, Germany), methanol (SigmaAldrich, Germany). Other materials used in the analysis and evaluation of the tablets were of analytical grade.

\section{Preparation of dissolution media}

SGF without enzymes was prepared by adding $42.4 \mathrm{ml}$ of concentrated $\mathrm{HCl}(36.5 \%)$ to $2.0 \mathrm{l}$ of distilled water. To this was added $10 \mathrm{~g}$ of sodium chloride and mixed until complete dissolution occurred. The solution was made up to $5.0 \mathrm{l}$ with distilled water. SIF without enzymes was prepared by dissolving $40 \mathrm{~g}$ of $\mathrm{NaOH}$ in distilled water and $34 \mathrm{~g}$ of monobasic potassium phosphate was added to obtain solutions of $\mathrm{pH} 7,7.2$ and 8. A $4 \mathrm{~g}$ quantity of $\mathrm{NaOH}$ was added to $100 \mathrm{ml}$ of distilled water. Stock A of PBS was prepared by adding $27.6 \mathrm{~g}$ of sodium dihydrogen phosphate monohydrate to $1000 \mathrm{ml}$ of distilled water. Stock B was prepared by adding $28.3 \mathrm{~g}$ of anhydrous disodium hydrogen phosphate to $1000 \mathrm{ml}$ of distilled water. A $200 \mathrm{ml}$ volume of $\mathrm{pH} 8$ was prepared by adding $8.3 \mathrm{ml}$ of stock A and $91.7 \mathrm{ml}$ of stock B to $100 \mathrm{ml}$ of distilled water. Also, 200 $\mathrm{ml}$ volume of $\mathrm{pH} 7.2$ was prepared by adding $28 \mathrm{ml}$ of stock A and 72 $\mathrm{ml}$ of stock B to $100 \mathrm{ml}$ of distilled water. Similarly, $200 \mathrm{ml}$ volume of $\mathrm{pH} 7$ was prepared by adding $39 \mathrm{ml}$ of stock A and $61 \mathrm{ml}$ of stock B to $100 \mathrm{ml}$ of distilled water. An $8.5 \mathrm{ml}$ volume of concentrated $\mathrm{HCl}$ (36.8\% purity and $1.18 \mathrm{~g} / \mathrm{ml}$ specific gravity) was added into 1000 $\mathrm{ml}$ of distilled water.

\section{Solubility profile of artesunate}

The degree of solubility of artesunate was determined in water, methanol, ethanol (96\%), ethanol/water mixtures (50/50, 40/60 v/v), SIF (pH 7, 7.2, 8), SGF (pH 1.2), $0.1 \mathrm{~N} \mathrm{HCl,} 0.1 \mathrm{~N} \mathrm{NaOH}, 0.1 \mathrm{~N}$ acetic acid, and PBS (pH 7, 7.2, 8). This was done by adding $50 \mathrm{mg}$ of artesunate into a volume of $100 \mathrm{ml}$ of individual medium and allowing it to stand for $3 \mathrm{~h}$. It was then filtered with pre-weighed filter paper, which was dried after and the amount dissolved calculated by difference. This was repeated twice for each medium and the average in each case obtained.

\section{Beer's plot}

A spectrophotometric scan of $100 \mathrm{mg} \%$ of artesunate solution in ethanol, $0.1 \mathrm{~N} \mathrm{NaOH}, 0.1 \mathrm{~N}$ acetic acid, methanol, SIF, SGF, serum/NaOH mixture and alcohol/water mixture was carried out and wavelengths of peak absorbance were obtained in each medium. The plot of absorbance against concentration (Beer's plot) in each medium was then made.

\section{Preparation of artesunate granules}

Four batches of artesunate granules were prepared by non-aqueous wet granulation method to avoid unwanted swelling of HPMC which could occur in granulation fluid. Therefore, ethanol/water mixture was employed $(50 / 50 \mathrm{w} / \mathrm{w})$. HPMC was incorporated at the concentrations of $10 \%, 20 \%, 25 \%$ and $30 \%$ of the tablet weight.

Appropriate quantities of artesunate and lactose powders were thoroughly mixed. The mixed powders were wet-massed with HPMC paste to form a homogenous adhesive damp mass. The wet mass was passed through sieve no. $10(17 \mathrm{~mm})$ and dried in hot air oven at $50{ }^{\circ} \mathrm{C}$ for one hour. The dried granules were then passed through sieve no. $16(1.0 \mathrm{~mm})$. The dried granules were characterized before compression. The formulae for all the batches are shown in table (1).

Table 1: Formula for preparation of artesunate tablets formulated with various concentrations of HPMC

\begin{tabular}{|c|c|c|c|c|}
\hline & Batch A* & Batch B* & Batch C* & Batch D* \\
\hline Artesunate (mg) & 450 & 450 & 400 & 400 \\
\hline HPMC (mg) & 60 & 120 & 150 & 180 \\
\hline Lactose (mg) & 78 & 18 & 38 & 8 \\
\hline Stearic acid (mg) & 12 & 12 & 12 & 12 \\
\hline Total (mg) & 600 & 600 & 600 & 600 \\
\hline
\end{tabular}

*Batches A, B, C and D were formulated with $10 \%, 20 \%, 25 \%$ and $30 \%$ of HPMC, respectively

The dose of artesunate incorporated into each tablet of batches $\mathrm{A}$ and $\mathrm{B}$ was determined by calculation as presented below:

$$
S D=h k D+(D-R t p) \ldots \ldots \ldots \ldots . . .(1)
$$

Where $\mathrm{SD}$ is sustained release dose, $\mathrm{h}=$ desired duration of release $=$ $12 \mathrm{~h}, \mathrm{R}=$ availability rate $=35 \mathrm{mg} / \mathrm{h}=\mathrm{KD}, k=$ elimination rate constant $=0.693 / \mathrm{t}_{1 / 2}, \mathrm{D}=$ initial dose $=100 \mathrm{mg}, \mathrm{t}_{1 / 2}=$ biological half $=$ $2 \mathrm{~h}$, and $\mathrm{t}_{\mathrm{p}}=$ time for peak plasma level $=2 \mathrm{~h}$.

For batches, $\mathrm{C}$ and $\mathrm{D}$, the typical administration dose of a drug in the conventional dosage form will give some indication of the total amount needed in the controlled release preparation $200 \mathrm{mg}$ b. i. $\mathrm{d}=400 \mathrm{mg}$.

\section{Determination of some flow and density properties}

The angle of repose (the maximum angle possible between the surface of a heap of powder and the horizontal plane) [9], flow rate, bulk and tapped densities, Carr's and Hausner's quotients [10] were all determined for each batch. A mean of three readings was then taken for each determined parameter.

\section{Preparation and evaluation of artesunate matrix tablets}

The artesunate granules of batches A to D were compressed on an F3 Manesty single punch tabletting machine (Manesty England) at a constant compression load of $50 \mathrm{kN}$. The performance of the compressed tablets was evaluated by employing hardness test, uniformity of weight, content uniformity, friability test, and absolute drug content and release studies [11, 12].

\section{Weight variation}

Twenty tablets were randomly selected from each batch and weighed individually. The mean weights and percentage deviation were calculated and recorded. This was done according to USP $[12,13]$

\section{Friability test}

Ten tablets from each batch were used and method reported by various workers was employed [12,14-16]. The tablets were dusted, weighed $\left(w_{i}\right)$ and put in Erweka model friabilator (Roche, England). The friabilator was operated for $4 \mathrm{~min}$ at $25 \mathrm{rpm}$. The tablets were then brought out, dusted and reweighed and the final weights $\left(w_{\mathrm{f}}\right)$ recorded. Friability (B) was calculated as a percentage weight loss using the equation below:

$$
\mathrm{B}=100 . \frac{\mathrm{wi}-\mathrm{wf}}{\mathrm{wi}}
$$

Values in the range of $0.8-1 \%$ are frequently quoted as the upper level of acceptance for pharmaceutical products or up to $20 \%$ for directly compressed products [14].

\section{Tablet strength}

Mosanto hardness tester (Manesty, England) was used to determine the hardness of the tablets [16] by noting the load or pressure 
required to crush each tablet. Ten tablets were used in each batch. The tablet was placed between the anvil and plunger. Pressure was then applied to the tablet via the plunger by means of a screw until the tablet fractured and the crushing strength read and recorded.

\section{Absolute drug content and content uniformity}

Method recorded by Bhosale et al. was modified and employed [16]: Five tablets from each batch were weighed and their mean weighed obtained. They were then crushed and a quantity each equivalent to the mean weight was weighed and dissolved in $900 \mathrm{ml}$ of ethanol; $900 \mathrm{ml}$ of $0.1 \mathrm{~N} \mathrm{NaOH}$ and $900 \mathrm{ml}$ of methanol. The values of absorbance were taken after dilution at $288 \mathrm{~nm}, 237 \mathrm{~nm}$ and $222 \mathrm{~nm}$ in $0.1 \mathrm{~N} \mathrm{NaOH}$, ethanol and amounts of the drug were calculated with reference to their respective Beer's plots. Twenty tablets from each batch were individually assayed spectrophotometrically in $0.1 \mathrm{~N}$ $\mathrm{NaOH}$ and ethanol.

\section{Dissolution and release studies}

\section{In vitro studies}

In vitro release of artesunate was determined in $0.1 \mathrm{~N} \mathrm{NaOH}, \mathrm{SGF}, \mathrm{SIF}$ and ethanol/water mixture for the four batches of the tablets using a standard United States pharmacopoeia rotating paddle apparatus (method II) (Erweka, Germany) [13, 17-19]. A $900 \mathrm{ml}$ of the dissolution medium was to ensure sink condition at $50 \mathrm{rpm}$. The dissolution experiment was carried out at $37 \pm 1{ }^{\circ} \mathrm{C}$. At each predetermined time interval, $5 \mathrm{ml}$ sample was withdrawn and replaced with the fresh dissolution medium. The samples withdrawn were diluted appropriately after filtration and the absorbance values determined at their individual wavelengths followed by concentrations and amounts determination. Release profiles of the different batches were plotted and $\mathrm{T}_{30 \%}, \mathrm{~T}_{50 \%}, \mathrm{~T}_{70 \%}$ and $\mathrm{C}_{\max }$ evaluated. From the data obtained, in vitro release kinetics was then investigated using the following models: Zero order, First order, Higuchi and Korsmeyer equations.

\section{In vivo studies}

Healthy Wistar albino rats of either sex weighing between 200 and $210 \mathrm{~g}$, used for this study were maintained at housing conditions of $24 \pm 2{ }^{\circ} \mathrm{C}$ temperature and $55 \%$ relative humidity with $12 \mathrm{~h}$ light. The animals were fed with a commercial diet and potable water provided ad libitum throughout the study. Official permission for the animal experimental procedures was granted by the Ethics Committee of Faculty of Pharmacy, University of Uyo, Uyo, Nigeria (approval number $\mathrm{UU} / \mathrm{PH} / 006$ ) and in conformity with the Federation of European Laboratory Animal Science Association and the European Community (Council Directive 86/609/EEC) of 1986 [20]

Calculated quantities of the drug were administered to four batches of rats at $125 \mathrm{mg} / \mathrm{kg}$. Artesunate tablets were prepared as suspension and administered orally using appropriate oral dosing needles. The suspension was administered within $5 \mathrm{~min}$ of preparation. Blood samples were collected at a predetermined time interval and the serum obtained was analyzed spectrophotometrically after appropriate dilution with $0.1 \mathrm{~N} \mathrm{NaOH}$ and filtration at $280 \mathrm{~nm}$.

The AUC, $\mathrm{t}_{1 / 2}$ for the first four hours and $\mathrm{C}_{\max }$, were calculated using the trapezoid represented by:

$$
[\mathrm{AUC}]_{\mathrm{tn}-1}^{\mathrm{tn}}=\frac{\mathrm{Cn}-1+\mathrm{Cn}}{2}\left(\mathrm{t}_{\mathrm{n}}-\mathrm{t}_{\mathrm{n}-1}\right)
$$

Where $t_{n}=$ higher time interval of drug concentration $C_{n} t_{n-1}=$ lower time interval for drug concentration $\mathrm{C}_{\mathrm{n}-1}$

$$
\mathrm{t}_{1 / 2}=\frac{0.693}{\mathrm{~K}} \text {.......... }
$$

K calculated from

$$
\log \mathrm{C}_{\mathrm{p}}=\log \mathrm{C}_{\mathrm{po}}-\frac{\mathrm{Kt}}{2.303} \ldots \ldots \ldots \ldots . . . .(5)
$$

$\mathrm{C}_{\mathrm{po}}$ and $\mathrm{C}_{\mathrm{p}}$ are plasma concentrations of the drug at the beginning and end of the time interval respectively.

\section{RESULTS AND DISCUSSION}

Artesunate was shown to be readily soluble in ethanol, methanol and $50 / 50(\mathrm{~V} / \mathrm{V})$ ethanol/water mixture. It was also soluble $0.1 \mathrm{~N}$ $\mathrm{NaOH}$ and $0.1 \mathrm{~N}$ acetic acid in the degrees as indicated in table (2). The observed solubility of artesunate in SIF is contrary to what was recorded in an earlier work [21]. This could be attributed to possible polymorphic behaviour or crystalline and amorphous behaviour. A polymorph is a solid material with at least two different molecular arrangements each of which gives a distinct crystal species. There are also large differences in their physical properties so that they behave as distinct chemical entities. Solubility, melting point, density, crystal shape, optical and electrical properties and vapour pressure are often very different for each polymorph. Unfortunately, artesunate has not been analyzed against the backdrop of polymorphism and these differences in solubility may have farreaching effects on its pharmacokinetics and pharmacodynamics. It is also possible that the two types of artesunate are different salts.

From Beer's plots, values of absorbance $\mathrm{A}$ of artesunate in various media are: SIF (pH 7.2) $\mathrm{A}=0.0013 \mathrm{C}$ at $220 \mathrm{~nm}$, SGF (pH 1.2) $\mathrm{A}=$ $0.009 \mathrm{C}$ at $253 \mathrm{~nm}, 0.1 \mathrm{~N} \mathrm{NaOH} \mathrm{A} 0.0212 \mathrm{C}$ at $288 \mathrm{~nm}, \mathrm{NaOH} /$ serum $\mathrm{A}$ $=0.007 \mathrm{C}$ at $288 \mathrm{~nm}$, acetic acid $\mathrm{A}=0.023 \mathrm{C}$ at $219 \mathrm{~nm}$, ethanol/water $50 / 50 \mathrm{v} / \mathrm{v}, \mathrm{A}=0.0122 \mathrm{C}$ at $216 \mathrm{~nm}$, methanol $\mathrm{A}$ $0.0027 \mathrm{C}$ at $222 \mathrm{~nm}$, ethanol $\mathrm{A}=0.003 \mathrm{C} 237 \mathrm{~nm}$. The wavelength of maximum absorption for the two types of artesunate are $287 \mathrm{~nm}$ and $288 \mathrm{~nm}$ which indicates that the two types may have the same

\begin{tabular}{|c|c|c|c|c|c|c|c|c|c|c|c|c|c|c|}
\hline \multicolumn{15}{|l|}{ Media } \\
\hline Water & Methanol & Ethanol & $\begin{array}{l}\text { Ethanol/water } \\
\mathbf{5 0 / 5 0} \mathrm{v} / \mathrm{v}\end{array}$ & $\begin{array}{l}\text { Ethanol/water } \\
40 / 60 \mathrm{v} / \mathrm{v}\end{array}$ & $\begin{array}{l}\text { SIFa } \\
\text { (pH } \\
7.0)\end{array}$ & $\begin{array}{l}\text { SIFa } \\
\text { (pH } \\
7.2)\end{array}$ & $\begin{array}{l}\text { SIFa } \\
\text { (pH } \\
8.0)\end{array}$ & $\begin{array}{l}\text { SGFb } \\
\text { (pH 1.2) }\end{array}$ & $\begin{array}{l}0.1 \mathrm{~N} \\
\mathrm{HCl}\end{array}$ & $\begin{array}{l}0.1 \mathrm{~N} \\
\mathrm{NaOH}^{\mathrm{d}}\end{array}$ & $\begin{array}{l}\text { 0.1N } \\
\text { acetic } \\
\text { acid }\end{array}$ & $\begin{array}{l}\text { PBS }^{\text {e }} \\
\text { (pH 7) }\end{array}$ & $\begin{array}{l}\text { PBS } \\
\text { (pH } \\
7.2)\end{array}$ & $\begin{array}{l}\mathrm{PBS}^{\mathrm{e}}(\mathrm{pH} \\
\text { 8) }\end{array}$ \\
\hline \multicolumn{15}{|c|}{ Solubility (\%) } \\
\hline $26.0 \pm 1.3$ & $100.0 \pm 3.5$ & $100.0 \pm 3.1$ & $96.0 \pm 3.3$ & $20.0 \pm 1.1$ & $6.0 \pm 1.1$ & $6.6 \pm 1.3$ & $8.0 \pm 1.2$ & $20.0 \pm 1.0$ & $21 \pm 1.0$ & $70.0 \pm 1.0$ & $70.0 \pm 1.0$ & $0.0 \pm 0.0$ & $3.0 \pm 0.2$ & $4.0 \pm 0.4$ \\
\hline
\end{tabular}
chromophore.

Table 2: Solubility of artesunate in different media

Values are shown as mean $\pm \mathrm{SD}, \mathrm{n}=3$, aSIF: simulated intestinal fluid, bSGF: simulated gastric fluid, cHCl: hydrochloric acid, dNaOH: sodium hydroxide,

\begin{tabular}{|c|c|c|c|c|c|c|}
\hline Batch & Bulk density $\left(\mathrm{g} / \mathrm{cm}^{3}\right)$ & Tapped density $\left(\mathrm{g} / \mathrm{cm}^{3}\right)$ & Hausner's ratio & Flow rate $(\mathrm{g} / \mathrm{s})$ & Carr's index & Angle of repose (\%) \\
\hline A & $0.48 \pm 0.01$ & $0.56 \pm 0.008$ & $1.17 \pm 0.05$ & $3.38 \pm 0.15$ & $14.28 \pm 0.81$ & $33.71 \pm 1.77$ \\
\hline B & $0.47 \pm 0.01$ & $0.53 \pm 0.010$ & $1.14 \pm 0.04$ & $3.35 \pm 0.18$ & $12.08 \pm 1.16$ & $34.57 \pm 1.39$ \\
\hline $\mathrm{C}$ & $0.47 \pm 0.00$ & $0.55 \pm 0.010$ & $1.17 \pm 0.06$ & $3.16 \pm 0.15$ & $14.55 \pm 1.21$ & $30.03 \pm 2.15$ \\
\hline D & $0.45 \pm 0.02$ & $0.50 \pm 0.010$ & $1.11 \pm 0.02$ & $3.17 \pm 0.16$ & $10.35 \pm 1.09$ & $30.03 \pm 1.95$ \\
\hline
\end{tabular}
ePBS: phosphate buffer solution

Table 3: Some micromeritic properties of the artesunate granules

Values are shown as mean \pm SD, $n=3$ 
From the micromeritic table (table 3), batch D exhibited excellent flow while batches, A, B and C had good flow. The better flowability of batch D could be attributable to its high concentration of HPMC as a binder in granulation.

Hausner found out that the ratio of tapped density to bulk density was related to the inter-particulate friction and as such could be used to predict the flow of granules. Less cohesive granules such as coarse spheres have ratios of approximately 1.2, whereas more cohesive less free-flowing powders such as flakes has Hausner's ratio greater than 1.6. From the above table, it could be seen that all the batches have Hausner's ratio close to 1.2, which indicates their free-flowing batch and could still be attributable to its higher content of HPMC.

According to Wells and Aulton [10], values of angle of repose less that 25 indicate excellent flow while values between 25 and 30 show good flow. Values between 30 and 40 indicate good flow that would be improved. However, the exact value of the angle of repose can depend on the method of measurement. The values in the table indicate good flow in all the batches and their values also lie within a close range. Lower angle of repose is widely known to correspond to higher flow of granules/powders. The values of angle of repose,
Carr's compressibility index and Hausner's ratio corroborate the flow rate as presented in table (3). Generally, the values of each parameter within the batches were significantly different $(p<0.05)$.

The limits of acceptance or rejection of tablet batches based on the content of active ingredient or assay are usually presented in the individual drug monogram.

Tables (4 to 7) show some of the properties of the tablets. All the batches were of good mechanical strength with low friability values indicating that they can withstand the stress associated with transportation, dispensing and storage processes. For friability, values in the range of $0.8-1 \%$ are frequently quoted as the upper level of acceptance for pharmaceutical products $[13,14]$. Their values were not up to such limit and are perfectly acceptable. The individual weights of the tablets in each batch were fairly uniform. None of the tablets deviated up to $5 \%$ of the mean weight in each batch. Although the tablets weighed fairly uniformly, most of them deviated from the target weight of $600 \mathrm{mg}$ which could be as a result of uneven die filling. Hardness values increased progressively as HPMC binder concentration increased (that is from batches A to D) with statistically insignificant difference in values $(p>0.05)$. The values of friability were low but were significant $(\mathrm{p}<0.05)$ among the batches.

Table 4: Some properties of sustained release artesunate matrix tablets

\begin{tabular}{lllll}
\hline Batch & Mean weight (mg) & Hardness (kgF) & Friability (\%) & Absolute drug content (mg) \\
\hline A & $594.00 \pm 12.26$ & $7.70 \pm 0.54$ & $0.29 \pm 0.013$ & $345.00 \pm 4.04$ \\
B & $594.60 \pm 13.63$ & $7.76 \pm 1.10$ & $0.32 \pm 0.012$ & $338.00 \pm 2.31$ \\
C & $593.20 \pm 14.50$ & $8.20 \pm 1.10$ & $0.28 \pm 0.008$ & $305.33 \pm 9.01$ \\
D & $597.00 \pm 15.70$ & $8.65 \pm 1.15$ & $0.29 \pm 0.011$ & $303.00 \pm 5.97$ \\
\hline
\end{tabular}

Values are shown as mean $\pm S D, n=3$

All the batches performed fairly well in content uniformity. According to official books, when ten tablets are assayed individual, the batch fails to comply if more than one tablet is outside the range of $85 \%$ to $115 \%$ of the average value or if any tablet is outside the range of $75 \%$ to $125 \%$ of the average [22]. Batch $\mathrm{A}$ as assayed in $\mathrm{NaOH}$ does not comply as they contain tablets with $130 \%$ and $72 \%$ releases.

Batches A and D as assayed in ethanol have tablets outside the stipulated range. Batches B and C complied both as assayed in $0.1 \mathrm{~N}$ $\mathrm{NaOH}$ and ethanol. Although most tablets in each of the batches were fairly uniform in terms of artesunate content, their mean values were all far from the labeled/target content strengths of 450 $\mathrm{mg}$ and $400 \mathrm{mg}$ of artesunate. It is also worthy of note that while the absolute drug content was fairly uniform in the batches, neither $\mathrm{NaOH}$ nor ethanol assay produced tablets of equal artesunate content as incorporated. Whereas tablets were of lower content as assayed in $\mathrm{NaOH}$ the values were higher with the assay in ethanol. The low values in the former could be attributed to the fact that artesunate, as shown in solubility profile, is only $70 \%$ soluble in $\mathrm{NaOH}$ and absorption interference could be the reasons for higher values increase of ethanol and methanol as assay media.

From fig. (1), batch D has the highest maximum percentage release followed by batch $\mathrm{B}$. Batch $\mathrm{C}$ has the least maximum percent release. The times of $30 \%, 50 \%$ and $70 \%$ release increased from batch A to batch $\mathrm{D}$. This is in line with the increasing order of HPMC concentration. Batch D which has the highest HPMC of $30 \%$, HPMC has $6.25,11$, and $18 \mathrm{~h}$ for $\mathrm{T}_{30 \%}, \mathrm{~T}_{50 \%}$ and $\mathrm{T}_{70 \%}$ respectively. Batch $\mathrm{A}$ which has the least concentration of HPMC recorded 1,3 , and $8 \mathrm{~h}$ for $\mathrm{T}_{30 \%}, \mathrm{~T}_{50 \%}$ and $\mathrm{T}_{70 \%}$ respectively. Batch C did not release up to $70 \%$ of artesunate and as such has no value for $\mathrm{T}_{70 \%}$. Accordingly, all the batches sustained the release of artesunate according to their percentage content of HPMC. $\mathrm{C}_{\max }$ for all the batches was in a close range and around $70 \%$ as indicated in absolute drug content test and with regard to $70 \%$ solubility of artesunate in $0.1 \mathrm{~N} \mathrm{NaOH}$. For all the batches, release rates were significantly different $(\mathrm{p}<0.05)$

Table 5: Some release parameters of artesunate matrix tablets in $0.1 \mathrm{~N} \mathrm{NaOH}$

\begin{tabular}{lllll}
\hline Batch & $\mathbf{T}_{\mathbf{3 0 \%}}{ }^{*}(\mathbf{h})$ & $\mathbf{T}_{\mathbf{5 0} \%}{ }^{*}(\mathbf{h})$ & $\mathbf{T}_{\mathbf{7 0} \%}{ }^{*}(\mathbf{h})$ & $\mathbf{C}_{\max } *^{*}(\mathbf{\%})$ \\
\hline A & 1.00 & 3.00 & 8.00 & 70 \\
B & 2.00 & 5.50 & 10.00 & 71 \\
C & 3.00 & 7.50 & - & 63 \\
D & 6.26 & 11.00 & 18.00 & 73 \\
\hline
\end{tabular}

${ }^{*} \mathrm{~T}_{30 \%}, \mathrm{~T}_{50 \%}$ and $\mathrm{T}_{70 \%}$, are the times required for $30 \%, 50 \%$ and $70 \%$ of artesunate to be released respectively, ${ }^{* *} \mathrm{C}_{\max }$ is the maximum drug concentration obtained for each batch

Table 6: Release kinetics model of artesunate from the different matrices

\begin{tabular}{|c|c|c|c|c|c|c|c|c|}
\hline \multirow[t]{2}{*}{ Batch } & \multicolumn{2}{|c|}{ Zero-order } & \multicolumn{2}{|c|}{ First order } & \multicolumn{2}{|l|}{ Higuchi } & \multicolumn{2}{|c|}{ Korsmeyer } \\
\hline & $\mathbf{R}^{2}$ & $\mathrm{~K}\left(\mathbf{h}^{-1}\right)$ & $\mathbf{R}^{2}$ & $K\left(h^{-1}\right)$ & $\mathbf{R}^{2}$ & $K\left(h^{-1}\right)$ & $\mathbf{R}^{2}$ & $\mathbf{N}$ \\
\hline $\mathrm{A}$ & -0.1666 & 41.2 & 0.4732 & 0.0241 & 0.7016 & 26.365 & 0.4492 & 1.0092 \\
\hline B & 0.8134 & 38.8 & 0.9340 & 0.0520 & 0.9060 & 23.318 & 0.6529 & 1.2126 \\
\hline C & 0.8991 & 30.2 & 0.9481 & 0.0461 & 0.9380 & 20.077 & 0.7449 & 1.2853 \\
\hline D & 0.9097 & 22.3 & 0.8801 & 0.3080 & 0.8974 & 14.165 & 0.7086 & 1.1391 \\
\hline
\end{tabular}




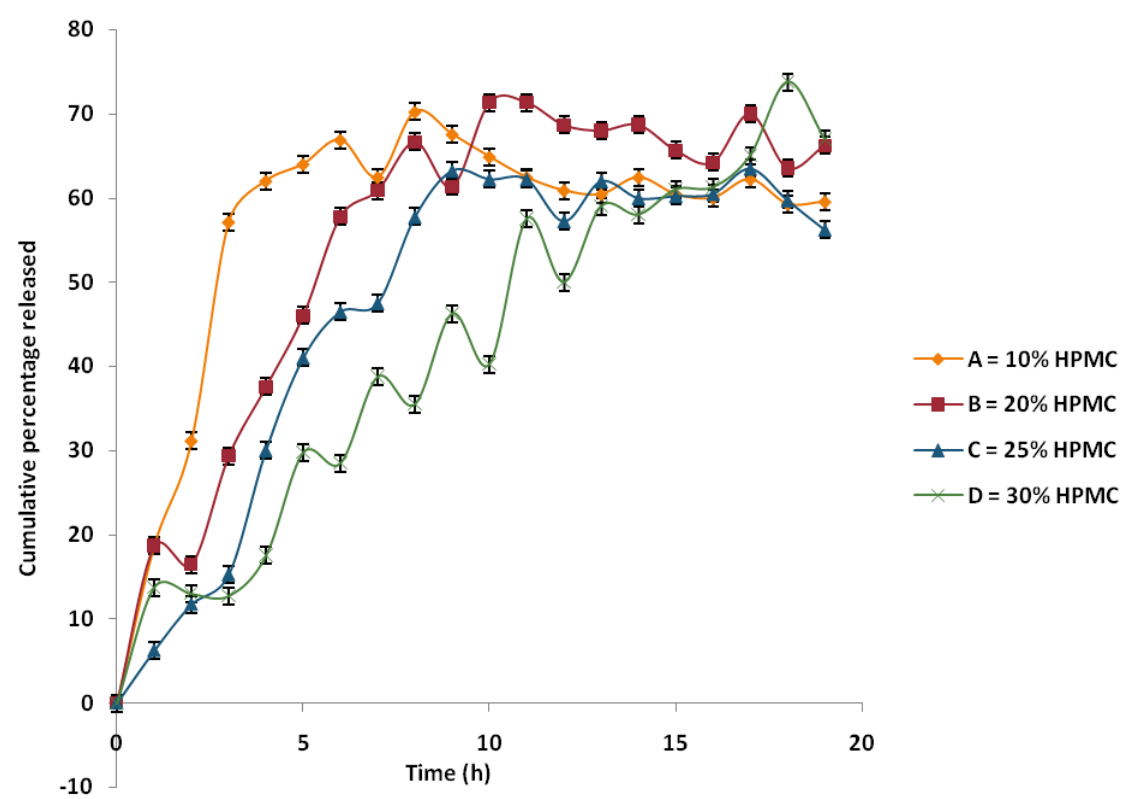

Fig. 1: Release profile of artesunate in $0.1 \mathrm{~N} \mathrm{NaOH}$

$\mathrm{n}=3$; the fig. was plotted from the average values of three (3) determinations of cumulative percentage of drug released

Batches B and C obeyed first-order kinetics in term of release. Batch A following Higuchi model while batch D followed of zero order.
Analysis using the Ritzer-Peppas model indicated that they all had complex release mechanism as the $n$ value in each batch was above 0.89 . The mechanism of release was the same probably because they all had HPMC as the binder.

Table 7: Parameters determined from in vivo release studies

\begin{tabular}{lllc}
\hline Batch & $\mathbf{T C}_{\max ^{\mathbf{a}} \mathbf{( h )}}$ & $\mathbf{T}_{\mathbf{1 / 2}} \mathbf{b}^{\mathbf{b}} \mathbf{( h )}$ & $\mathbf{A U C \mathbf { c }}(\boldsymbol{\mu g} / \mathbf{m l} / \mathbf{h})$ \\
\hline Control & 1.00 & 1.21 & 96.00 \\
A & 1.00 & 1.16 & 88.00 \\
B & 2.00 & 1.22 & 103.00 \\
C & 1.00 & 0.65 & 64.56 \\
D & 2.00 & 0.99 & 76.19 \\
Mean & - & 1.05 & - \\
\hline
\end{tabular}

aTime taken to obtain maximum concentration $\left(\mathrm{TC}_{\max }\right.$ ), bhalf-life $\left(\mathrm{T}_{1 / 2}\right)$ and carea under curve (AUC) were derived from in vivo release plots

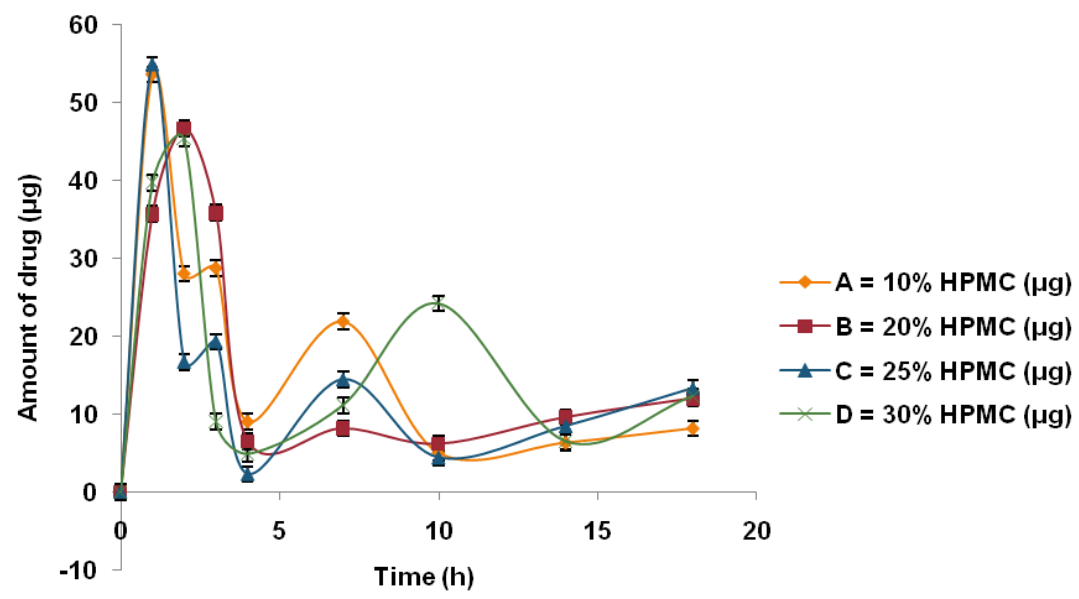

Fig. 2: Plots of the amount of artesunate released from the different matrices per unit time

$\mathrm{n}=3$; the fig. was plotted from the average values of three (3) determinations of the amount of drug released per unit time.

The values of $\mathrm{T}_{\text {cmax }}$ in the in vivo study indicated that all the batches had a maximum concentration within the first $1 \mathrm{~h}$ except batch $\mathrm{B}$ that was at $2 \mathrm{~h}$. The values were in close range. From the result, the sustained release properties of the batches were not completely reflected. This could be attributed to the fact that the tablets had to be crushed and suspended in water prior to administration thereby countering the effect of the binder and more so as HPMC is soluble in water. The $t_{1 / 2}$ value of $1.05 \mathrm{~h}$ also supports the reason for subjecting artesunate to sustained release delivery. The AUC values indicate that they were in a 
close range. As shown in fig. 2, there was an increase in the amount of artesunate after the fourth hour. This could be attributed to the fact that artesunate in the living system may have produced metabolites that absorb at the same wavelength of artesunate.

\section{CONCLUSION}

The development of drug substance cannot be said to be complete until an appropriate assay method both in vitro and in vivo have evolved. The identities of different drug substances are of paramount importance in an attempt to develop an assay method. The solubility of artesunate generally varies with media used. Many drugs may exist in more than one polymorphs and that could account for variation in solubility of artesunate in SIF. The wavelength of a maximum of absorption of the two types of artesunate was $287 \mathrm{~nm}$ and $288 \mathrm{~nm}$ indicating the presence of the same chromophore but possibly different crystal form.

The release kinetics obtained showed that zero order, first order and Higuchi model kinetics were involved in the release of artesunate from the tablet. The mechanism of release was shown to be complex.

In vivo studies showed the high release of artesunate and biological half-life of artesunate is $1.05 \mathrm{~h}$.

\section{ACKNOWLEDGEMENT}

The authors are grateful to the entire technical staff of Department of Pharmaceutics, Faculty of Pharmaceutical Sciences, University of Nigeria, Nsukka, Nigeria.

\section{AUTHORS' CONTRIBUTION}

This work was collaboratively carried out by all the three authors as regards the concept and design of the work, collection, assembly, data analysis and interpretation, writing, critical revision and approval of the final manuscript for publication.

\section{CONFLICTS OF INTERESTS}

\section{Declared none}

\section{REFERENCES}

1. Thomas WYL, Joseph RR. Controlled release drug delivery of the system. In: Alfonso RG, editor. Remingtons: the science and practice of pharmacy. USA: Lippincott Williams and Wilkins; 2000. p. 903-9.

2. Singh BN, Kim KH. Floating drug delivery systems: An approach to oral controlled drug delivery via gastric retention. J Controlled Release 2000;63:235-59.

3. Roy H, Brahma CK, Nandi S, Parida KR. Formulation and design of sustained release matrix tablets of metformin hydrochloride: Influence of hypromellose and polyacrylate polymers. Int J Appl Basic Med Res 2013;3:55-63.
4. Rowe RC, Sheskey PJ, Quinn ME. editors. Handbook of pharmaceutical excipients. $6^{\text {th }}$ ed. London: Pharmaceutical Press: American Pharmacists Association; 2009.

5. Chowhan ZT. Role of Binder in moisture induced hardness increase in compressed tablets its effect on in vitro disintegration and dissolution. J Pharm Sci 1980;61:1-4.

6. Banker G. Evaluation of HPC and HPMC as an aqueous-based film coating. Drug Dev Ind Pharm 1981;71:693-716.

7. Hein TT, White NJ. Quinghaosu. Lancet 1993;341:603-8.

8. Basco LK, Brass J. In vitro activity of artemisinin derivative against African isolates and clones of Plasmodium falciparum. Am J Trop Med Hyg 1993;49:301-7.

9. Alfred M. Miccromerites. In: Physical pharmacy. London: Lippincott Williams Wilkins; 1993. p. 447.

10. Wells JI, Aulton ME. Preformulation. In: Pharmaceutics: The science of dosage forms design. Aulton ME. editor. London: Churchill Livingstone; 1999. p. 348.

11. Chukka S, Shaik S. Development and characterization of gastroretentive drug delivery system for ritonavir tablets using natural polymers. Asian J Pharm Clin Res 2017;10:318-22.

12. Roy SKR, Naskar S, Kundu S, Koutsu K. Formulation and evaluation of sustained release bi-layer tablets of propranolol hydrochloride. Int J Pharm Pharm Sci 2014;7:264-9.

13. The United States Pharmacopoeia/National Formulary, USP 37/NF 32, Vol. I. The United States Pharmacopoeial Convention, Timbrook Parkway, Rockville: 2014. p. 342-344, $487,1146$.

14. Ofoefule SI. A textbook of pharmaceutical techology and industrial pharmacy. Lagos: Samakin Nig. Ent; 2002.

15. Adedokun MO, Itiola OA. Material properties and compaction characteristics of natural and pregelatinized forms of four starches. Carbohydr Polym 2010;79:818-24.

16. Bhosale RR, Riyaz AM, Osmani PC, Moin A. Formulation and evaluation of sustained release dosage form using modified cashew gum. Int J Pharm Pharm Sci 2015;7:141-50.

17. Kalita B, Saikia K, Kalita B. Development and characterization of mucoadhesive microsphere-loaded intranasal gel of venlafaxine hydrochloride. Asian J Pharm Clin Res 2016;9:139-44.

18. Deshmukh MT, Mohite SK. Formulation and characterization of olanzapine-loaded mucoadhesive microspheres. Asian J Pharm Clin Res 2017;10:249-55.

19. Mohite PB, Khanage SG, Harishchandre VS, Shirsath Y. Recent advances in microsponges drug delivery system. J Crit Rev 2016;3:9-16.

20. European Community Council Directive on the ethics of experiments involving laboratory animals (86/609/EEC); 1986.

21. Esimone CO, Okeye FBC, Onah BU, Omeje EO, Nworu CS. In vitro bioequivalence study of nine brands of artesunate tablets marketed in Nigeria. J Vect Borne Dis 2008;45:61-6.

22. British Pharmacopoeia. Her Majesty's Stationary Office, London; 2002. 